\title{
RESPONS MAHASISWA TERHADAP PELAKSANAAN PROGRAM MATRIKULASI
}

\author{
Chandra Lesmana', Muhamad Arpan², Ambiyar ${ }^{3}$, \\ Wakhinuddin $^{4}$, Erni Fatmawati ${ }^{5}$ \\ ${ }^{1,2,5}$ Program Studi Pendidikan TIK, Fakultas MIPA dan Teknologi \\ IKIP PGRI Pontianak, Jalan Ampera Nomor 88 Pontianak - 78116 \\ ${ }^{3,4}$ Pendidikan Teknologi dan Kejuruan, Universitas Negeri Padang \\ Jalan Prof. Dr. Hamka, Air Tawar Barat, Kota Padang - 25171 \\ 1e-mail: chandralesmana87@gmail.com
}

\begin{abstract}
Abstrak
Program matrikulasi penting dilakukan sebagai persiapan bagi mahasiswa baru dalam menerima pembelajaran pada saat perkuliahan berlangsung. Penelitian bertujuan untuk mendeskripkan respons mahasiswa Program Studi Pendidikan TIK IKIP PGRI Pontianak tentang kegiatan matrikulasi yang dilaksanakan. Metode penelitian yaitu deskriptif. Responden penelitian yaitu seluruh mahasiswa yang mengikuti kegiatan matrikulasi tahun akademik 2019/2020 sebanyak 112 orang. Instrumen penelitian menggunakan angket tertutup. Teknik analisis data yang digunakan yaitu deskriptif-kuantitatif. Berdasarkan hasil analisis data penelitian, dapat disimpulkan bahwa: 74,11\% responden "Sangat Setuju" matrikulasi diadakan untuk topik Pendidikan Karakter; 77,68\% responden "Sangat Setuju" matrikulasi diadakan untuk topik Multimedia; 66,96\% responden "Sangat Setuju" matrikulasi diadakan untuk topik Rekayasa Perangkat Lunak; dan 63,39\% responden "Sangat Setuju" matrikulasi diadakan untuk topik Jaringan Komputer.
\end{abstract}

Kata Kunci: respons mahasiswa, Program Matrikulasi Pendidikan Karakter, Multimedia, Rekayasa Perangkat Lunak, Jaringan Komputer.

\section{Abstract}

The matriculation program is important as a preparation for new students to receive learning during lectures. The research aims to describe the response of ICT Education Teachers' Training Program IKIP PGRI Pontianak about matriculation activities carried out. The research method is descriptive. Research respondents were all students who participated in the matriculation activities of the 2019/2020 academic year as many as 112 people. The research instrument used a closed questionnaire. The data analysis technique used is descriptive-quantitative. Based on the results of the analysis of research data, it can be concluded that: $74.11 \%$ of respondents "Strongly Agree" matriculation was held for the topic of Character Education; $77.68 \%$ of respondents "Strongly Agree" matriculation was held for the topic of Multimedia; $66.96 \%$ of respondents "Strongly Agree" matriculation was held for the topic of Software Engineering; and 63.39\% of respondents "Strongly Agree" matriculation was held for the topic of Computer Networks.

Keywords: student responses, matriculation, Character Education, Multimedia, Software Engineering, Computer Networks. 


\section{PENDAHULUAN}

Program Studi Pendidikan Teknologi Informasi dan Komputer (Pendidikan TIK) IKIP PGRI Pontianak setiap tahunnya melaksanakan program matrikulasi bagi mahasiswa, khususnya mahasiswa baru. Matrikulasi merupakan penyetaraan ilmu yang ditujukan bagi calon mahasiswa yang dianggap belum mempunyai dasar keilmuan yang cukup untuk mengikuti perkuliahan (Departemen Pendidikan Nasional, 2002). Matrikulasi juga dapat diartikan sebagai kegiatan pembelajaran tambahan untuk menyetarakan pengetahuan peserta didik agar dapat mengikuti program pendidikan yang akan diikuti (Rektor Universitas Indonesia, 2008). Matrikulasi bertujuan untukmemberikan bekal pengetahuan pendidikan yang berkaitan dengan pengembangan bahan ajar, pemahaan tentang peserta didik, penguasaan tentang peserta didik, penguasaan pembelajatan yang mendidik, pengembangan kepribadian, dan keprofesionalan (Anwar, 2012).

Program matrikulasi yang dilaksanakan Program Studi Pendidikan TIK terbagi menjadi 4 topik, yaitu Pendidikan Karakter, Multimedia, Rekayasa Perangkat Lunak, dan Jaringan Komputer. Pemateri dalam program matrikulasi tersebut adalah dosen-dosen dari Program Studi Pendidikan TIK. Program matrikulasi penting untuk dilakukan sebagai pengenalan umum mengenai materi yang akan diterapkan di Program Studi Pendidikan TIK. Program matrikulasi juga dijadikan sebagai persiapan mahasiswa dalam menerima mata kuliah yang akan ditempuh pada saat perkuliahan. Matrikulasi dilaksanakan setiap awal semester ganjil sebelum proses perkuliahan dimulai.

Program matrikulasi diharapkan akan berdampak pada peningkatan pengetahuan awal (dasar) dan perubahan diri mahasiswa ke arah yang lebih baik dikarenakan terjadinya proses belajar. Belajar adalah suatu proses untuk memperoleh motivasi dalam pengetahuan, keterampilan, kebiasaan, dan tingkah laku (Djamarah, 2008). Belajar diasumsikan sebagai perubahan kepribadian terkait kecakapan sikap, kebiasaan, dan kepandaian (Purwanto, 1986). Belajar merupakan modifikasi kelakuan melalui pengalaman (Hamalik, 2010). Belajar juga merupakan tahap perubahan kognitif, afektif, dan psikomotorik (Syah, 2008). Belajar menjadi syarat mutlak untuk menjadi pandai dalam bidang ilmu 
pengetahuan ataupun keterampilan (Mudzalir, 1997). Dengan dilaksanakannya program matrikulasi, kelancaran proses pembelajaran dalam perkuliahan diharapkan dapat membantu mahasiswa untuk lulus tepat waktu karena telah memiliki dasar pengetahuan tentang proses pembelajaran yang akan dilaksanakan serta terjadi perubahan tingkah laku yang lebih baik.

Keberhasilan pelaksanaan program matrikulasi dapat diketahui berdasarkan hasil evaluasi yang dilakukan. Salah satu cara untuk melakukan evaluasi yaitu dengan menganalisis respons dari peserta matrikulasi. Respons adalah setiap tingkah laku yang pada hakekatnya merupakan tanggapan atau balasan terhadap suatu rangsangan atau stimulus (Meinarno dan Sarwono, 2010). Respons juga diartikan sebagai sikap atau tingkah laku, pengaruh atau penolakan, suka atau tidak suka, serta pemanfaatan pada suatu fenomena tertentu (Sobur, 2003). Respons adalah suatu reaksi yang bergantung pada stimulus yang diberikan (Gulo, 1996). Respons merupakan konsekuensi dari perilaku sebelumnya dan dianggap sebagai tanggapan ataupun jawaban terhadap sesuatu hal (Soekanto, 2007). Respons seseorang dapat dalam bentuk baik atau buruk, positif atau negatif (Azwar, 1998).

Evaluasi terhadap program matrikulasi yang dilaksanakan perlu dilakukan untuk mengetahui tanggapan para peserta tentang pelaksanaan program matrikulasi tersebut. Hasil dari evaluasi dapat dijadikan sebagai bahan pertimbangan dalam menyusun program kerja, termasuk topik-topik yang disampaikan pada program matrikulasi. Berdasarkan pada pertimbangan tersebut, maka dilakukan penelitan tentang respons mahasiswa terhadap pelaksanaan program matrikulasi. Penelitian bertujuan untuk mendeskripsikan respons mahasiswa Program Studi Pendidikan TIK IKIP PGRI Pontianak tentang program matrikulasi yang dilaksanakan setiap tahunnya oleh Program Studi Pendidikan TIK IKIP PGRI Pontianak.

\section{METODE}

Metode penelitian yang digunakan adalah deskriptif-kuantitatif. Data yang diperoleh dari penelitian, dianalisis dan ditampilkan dalam bentuk bagan maupun 
narasi. Lokasi penelitian di Program Studi Pendidikan TIK IKIP PGRI Pontianak. Responden penelitian yaitu mahasiswa Program Studi Pendidikan TIK IKIP PGRI Pontianak yang menjadi peserta program matrikulasi tahun akademik 2019/2020 dengan jumlah 112 orang.

Pengumpulan data menggunakan instrumen berupa angket tertutup. Angket tertutup digunakan untuk mengetahui respons para peserta program matrikulasi. Pada bagian akhir angket, diberikan kolom untuk para peserta menuliskan komentar atau saran terhadap pelaksanaan program matrikulasi. Penyebaran angket dilakukan secara daring kepada para peserta yang mengikuti program matrikulasi. Pengisian angket dilakukan setelah para peserta menyelesaikan proses matrikulasi pada setiap topik.

Tabel 1 Indikator dan Item Pertanyaan Angket

\begin{tabular}{cll}
\hline Indikator & \multicolumn{4}{c}{ Item Pertanyaan } \\
\hline Persetujuan & $\begin{array}{l}\text { Apakah Anda menyetujui diadakannya matrikulasi guna } \\
\text { mempersiapkan diri menghadapi perkuliahan? }\end{array}$ \\
Kesesuaian & $\begin{array}{l}\text { Apakah materi yang disampaikan pada saat matrikulasi sudah } \\
\text { sesuai dengan kompetensi yang diharapkan? }\end{array}$ \\
Pemahaman & Apakah anda memahami materi yang disampaikan oleh pemateri? \\
Kesenangan & $\begin{array}{l}\text { Apakah suasananya menyenangkan selama pelaksanaan } \\
\text { Matrikulasi? }\end{array}$ \\
\hline
\end{tabular}

Data penelitian diolah secara deskriptif-kuantitatif dengan menarasikan informasi yang disampaikan oleh responden memalui angket sesuai dengan substansi tujuan penelitian.

\section{HASIL DAN PEMBAHASAN}

Program matrikulasi terdiri dari 4 topik utama, yaitu Pendidikan Karakter, Multimedia, Rekayasa Perangkat Lunak, dan Jaringan Komputer. Hasil analisis data penelitian diuraikan berdasarkan pada indikator angket yang disebarkan kepada responden.

\section{Respons untuk Indikator Persetujuan}

Hasil analisis data respons mahasiswa terhadap pelaksanaan program matrikulasi yang dilaksanakan oleh Program Studi Pendidikan TIK IKIP PGRI 
Pontianak berdasarkan indikator persetujuan untuk setiap topik matrikulasi adalah sebagai berikut.

Tabel 2 Tabel Rekapitulasi Respons untuk Indikator Persetujuan

\begin{tabular}{lccccc}
\hline \multirow{2}{*}{ Topik } & \multicolumn{5}{c}{ Jumlah Jawaban Responden } \\
\cline { 2 - 6 } & $\begin{array}{c}\text { Sangat } \\
\text { Setuju }\end{array}$ & Setuju & $\begin{array}{c}\text { Tidak } \\
\text { Setuju }\end{array}$ & $\begin{array}{c}\text { Sangat } \\
\text { Tidak Setuju }\end{array}$ & Jumlah \\
\hline Pendidikan Karakter & 83 & 29 & 0 & 0 & 112 \\
Multimedia & 87 & 25 & 0 & 0 & 112 \\
Rekayasa Perangkat Lunak & 75 & 37 & 0 & 0 & 112 \\
Jaringan Komputer & 71 & 41 & 0 & 0 & 112 \\
\hline
\end{tabular}

Secara persentase, respons mahasiswa terhadap pelaksanaan program matrikulasi yang dilaksanakan oleh Program Studi Pendidikan TIK IKIP PGRI Pontianak berdasarkan indikator persetujuan untuk setiap topik matrikulasi adalah sebagai berikut.

\section{Respons untuk Indikator Persetujuan}

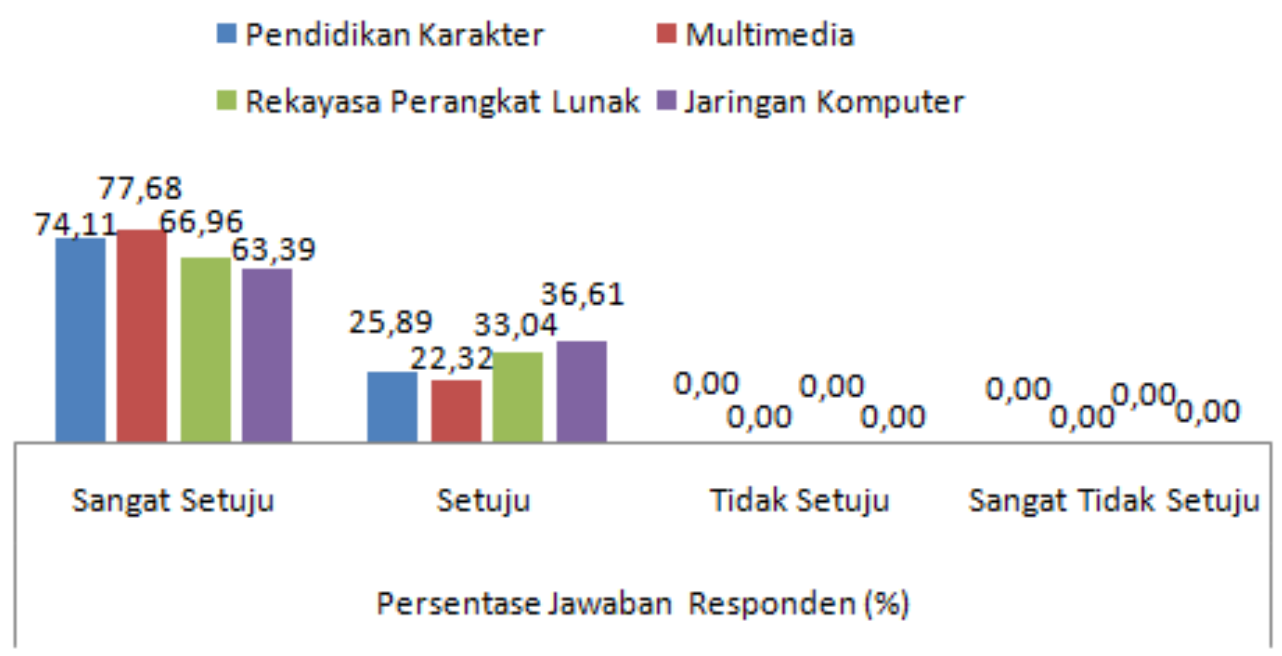

Gambar 1 Persentase Respons Mahasiswa untuk Indikator Persetujuan

\section{Respons untuk Indikator Kesesuaian}

Hasil analisis data respons mahasiswa terhadap pelaksanaan program matrikulasi yang dilaksanakan oleh Program Studi Pendidikan TIK IKIP PGRI Pontianak berdasarkan indikator kesesuaian untuk setiap topik matrikulasi adalah sebagai berikut. 
Tabel 3 Rekapitulasi Respons untuk Indikator Kesesuaian

\begin{tabular}{lccccc}
\hline \multirow{2}{*}{\multicolumn{1}{c}{ Topik }} & \multicolumn{5}{c}{ Jumlah Jawaban Responden } \\
\cline { 2 - 6 } & $\begin{array}{c}\text { Sangat } \\
\text { Sesuai }\end{array}$ & Sesuai & $\begin{array}{c}\text { Tidak } \\
\text { Sesuai }\end{array}$ & $\begin{array}{c}\text { Sangat } \\
\text { Tidak Sesuai }\end{array}$ & Jumlah \\
\hline Pendidikan Karakter & 53 & 58 & 1 & 0 & 112 \\
Multimedia & 48 & 64 & 0 & 0 & 112 \\
Rekayasa Perangkat Lunak & 48 & 59 & 4 & 1 & 112 \\
Jaringan Komputer & 51 & 60 & 1 & 0 & 112 \\
\hline
\end{tabular}

Secara persentase, respons mahasiswa terhadap pelaksanaan program matrikulasi yang dilaksanakan oleh Program Studi Pendidikan TIK IKIP PGRI Pontianak berdasarkan indikator kesesuaian untuk setiap topik matrikulasi adalah sebagai berikut.

\section{Respons untuk Indikator Kesesuaian}

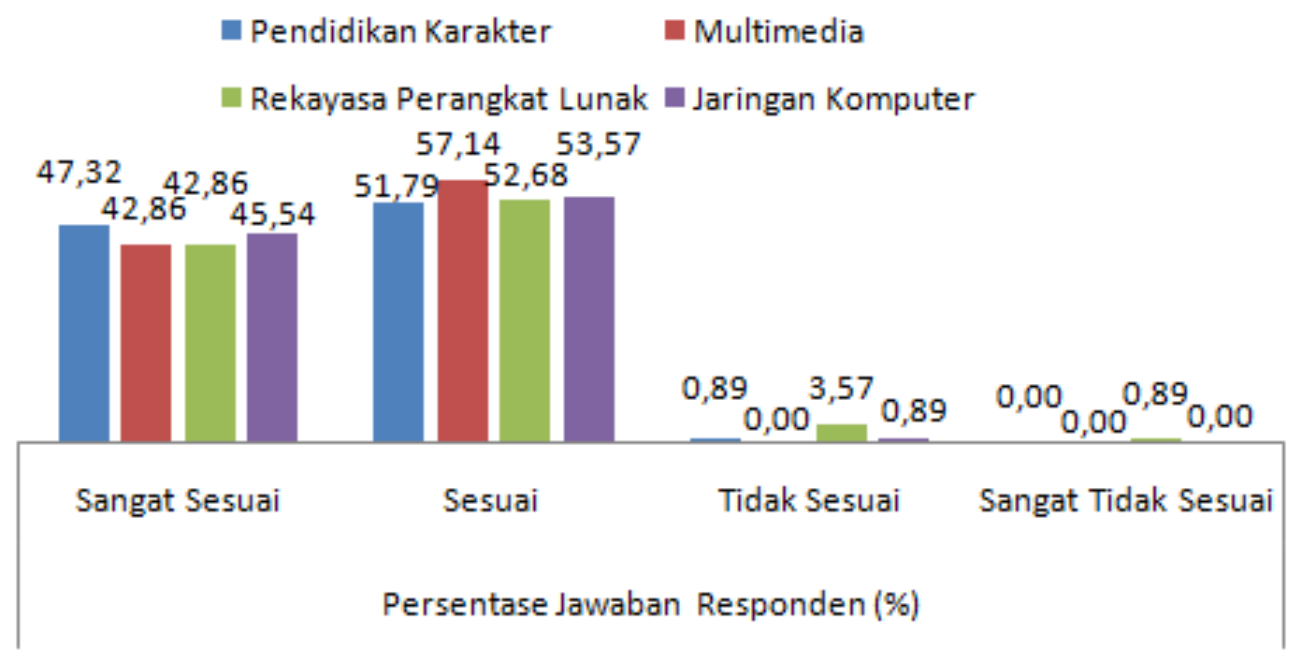

Gambar 2 Persentase Respons Mahasiswa untuk Indikator Kesesuaian

\section{Respons untuk Indikator Pemahaman}

Hasil analisis data respons mahasiswa terhadap pelaksanaan program matrikulasi yang dilaksanakan oleh Program Studi Pendidikan TIK IKIP PGRI Pontianak berdasarkan indikator pemahaman untuk setiap topik matrikulasi adalah sebagai berikut. 
Tabel 4 Tabel Rekapitulasi Respons untuk Indikator Pemahaman

\begin{tabular}{lccccc}
\hline \multirow{2}{*}{\multicolumn{1}{c}{ Topik }} & \multicolumn{5}{c}{ Jumlah Jawaban Responden } \\
\cline { 2 - 6 } & $\begin{array}{l}\text { Sangat } \\
\text { Paham }\end{array}$ & Paham & $\begin{array}{c}\text { Tidak } \\
\text { Paham }\end{array}$ & $\begin{array}{c}\text { Sangat } \\
\text { Tidak } \\
\text { Paham }\end{array}$ & Jumlah \\
\hline Pendidikan Karakter & 17 & 89 & 6 & 0 & 112 \\
Multimedia & 24 & 78 & 10 & 0 & 112 \\
Rekayasa Perangkat Lunak & 23 & 69 & 17 & 3 & 112 \\
Jaringan Komputer & 35 & 75 & 2 & 0 & 112 \\
\hline
\end{tabular}

Secara persentase, respons mahasiswa terhadap pelaksanaan program matrikulasi yang dilaksanakan oleh Program Studi Pendidikan TIK IKIP PGRI Pontianak berdasarkan indikator pemahaman untuk setiap topik matrikulasi adalah sebagai berikut.

\section{Respons untuk Indikator Pemahaman}

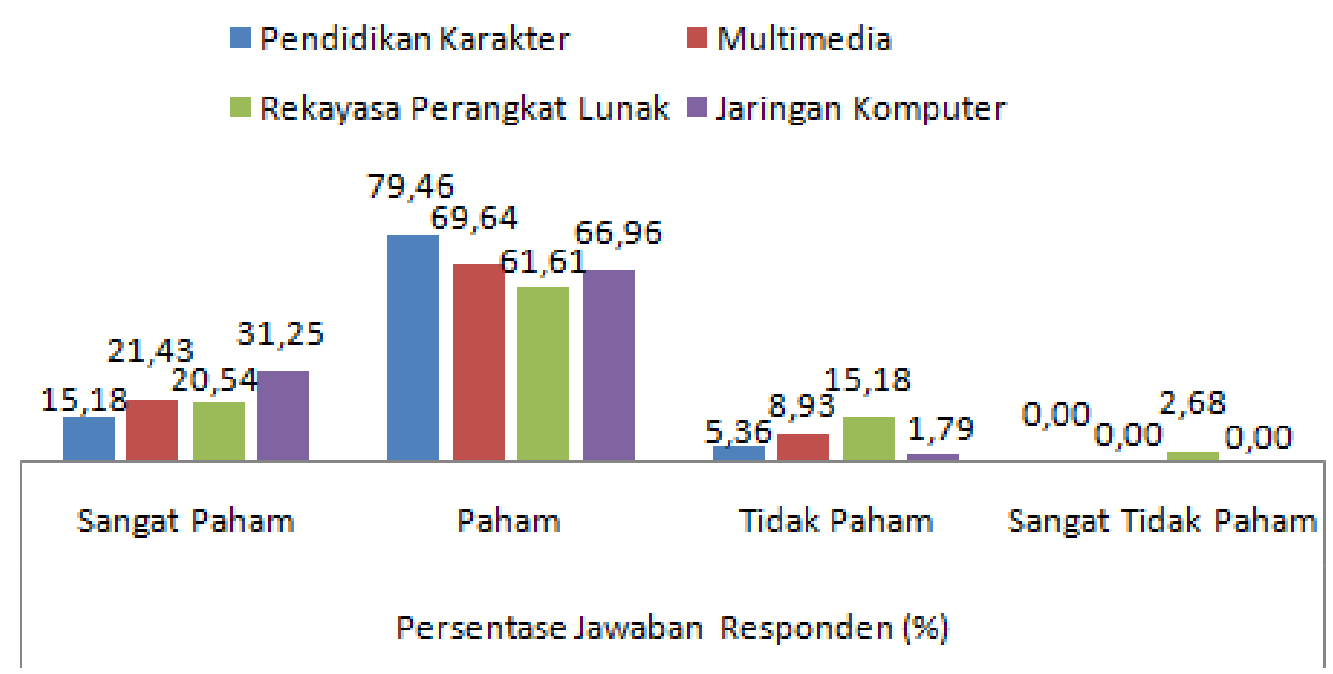

Gambar 3 Persentase Respons Mahasiswa untuk Indikator Pemahaman

\section{Respons untuk Indikator Kesenangan}

Hasil analisis data respons mahasiswa terhadap pelaksanaan program matrikulasi yang dilaksanakan oleh Program Studi Pendidikan TIK IKIP PGRI Pontianak berdasarkan indikator kesenangan untuk setiap topik matrikulasi adalah sebagai berikut. 
Tabel 5 Tabel Rekapitulasi Respons untuk Indikator Kesenangan

\begin{tabular}{lccccc}
\hline & \multicolumn{5}{c}{ Jumlah Jawaban Responden } \\
\cline { 2 - 6 } \multicolumn{1}{c}{ Topik } & $\begin{array}{c}\text { Sangat } \\
\text { Menye- } \\
\text { nangkan }\end{array}$ & $\begin{array}{c}\text { Menye } \\
\text { nang- } \\
\text { kan }\end{array}$ & $\begin{array}{c}\text { Tidak } \\
\text { Menye- } \\
\text { nangkan }\end{array}$ & $\begin{array}{c}\text { Sangat } \\
\text { Tidak } \\
\text { Menye- }\end{array}$ & Jumlah \\
& 60 & 50 & 2 & 0 & 112 \\
\hline Pendidikangkan Karakter & 50 & 61 & 1 & 0 & 112 \\
Multimedia & 47 & 51 & 12 & 2 & 112 \\
Rekayasa Perangkat Lunak & 55 & 56 & 1 & 0 & 112 \\
Jaringan Komputer & & & & & \\
\hline
\end{tabular}

Secara persentase, respons mahasiswa terhadap pelaksanaan program matrikulasi yang dilaksanakan oleh Program Studi Pendidikan TIK IKIP PGRI Pontianak berdasarkan indikator pemahaman untuk setiap topik matrikulasi adalah sebagai berikut.

\section{Respons untuk Indikator Kesenangan}

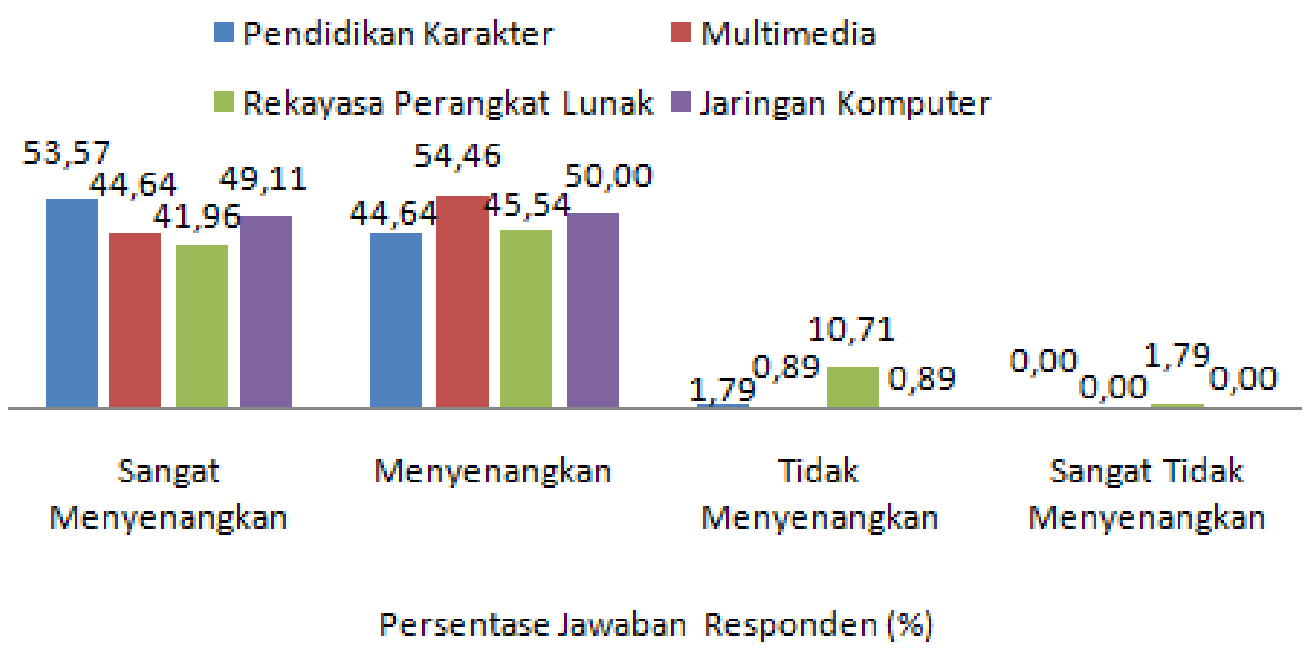

Gambar 4 Persentase Respons Mahasiswa untuk Indikator Kesenangan

Berdasarkan hasil analisis data penelitian yang telah diuraikan, diketahui bahwa kategori "Sangat Setuju" memiliki persentase paling besar untuk semua topik dalam program matrikulasi yang dilaksanakan. Hal tersebut diperkuat dengan komentar responden pada angket yang diberikan, bahwa materi tentang pendidikan karakter yang disampaikan membuat kesadaran diri akan karakter 
yang baik semakin bertambah. Hasil tersebut sesuai dengan penelitian Gunawan (2016) yang menyimpulkan bahwa kegiatan matrikulasi pendidikan seks berpengaruh positif signifikan terhadap karakter peserta didik Madrasah Ibtidaiyah (MI).

Responden memberikan komentar untuk topik Multimedia, bahwa materi yang disampaikan secara umum sesuai dengan apa yang ada dipikiran responden pada saat mendaftarkan diri ke Program Studi Pendidikan TIK IKIP PGRI Pontianak. Salah satunya adalah responden akan mendapatkan pembelajaran multimedia yang diharapkan akan meningkatkan kompetensi responden di bidang multimedia dalam mempersiapkan karier di bidang tersebut. Hasil tersebut sesuai dengan penelitian sebelumnya yang menyimpulkan bahwa kesesuaian minat, peluang karier, dan kompetensi yang memengaruhi pilihan mahasiswa dalam memilih program studi (Sunaiyah, 2018; Rosliana, dkk., 2014; Misran, et al., 2012; Herwandar, dkk., 2012).

Responden memberikan komentar untuk topik Jaringan Komputer, bahwa tata cara penyampaian materi oleh narasumber mudah dimengerti oleh responden. Hal tersebut membuat responden menjadi lebih termotivasi sehingga hasil belajar akan tercapai sesuai dengan tujuan pembelajaran. Hasil tersebut sesuai dengan penelitian sebelumnya yang menyimpulkan bahwa motivasi, kemauan, dan kemampuan pengendalian emosi merupakan faktor yang dapat memprediksi sikap dan hasil belajar (Prasad, et al. 2017; Kaptiningrum dan Mubarok, 2016; Mitchell and Stewart, 2012; Jeremy, et al., 2012; Nurnberg, et al., 2012).

Responden memberikan komentar untuk topik Rekayasa Perangkat Lunak, bahwa teknik penyampaian materi oleh narasumber menarik dan suasana saat program matrikulasi berlangsung menyenangkan, sehingga responden tidak merasakan kebosanan. Terjadi interaksi yang baik antara responden dan narasumber, serta responden dan responden dalam proses pelaksanaan program matrikulasi. Hal tersebut sesuai dengan hasil penelitian sebelumnya yang menyimpulkan bahwa program matrikulasi terlaksana dengan menyenangkan (Syahadati, et al., 2018; Hartati, 2017). 


\section{SIMPULAN}

Berdasarkan hasil analisis data penelitian, maka disimpulkan: 74,11\% responden "Sangat Setuju” matrikulasi diadakan untuk topik Pendidikan Karakter; 77,68\% responden "Sangat Setuju" matrikulasi diadakan untuk topik Multimedia; $66,96 \%$ responden "Sangat Setuju" matrikulasi diadakan untuk topik Rekayasa Perangkat Lunak; dan 63,39\% responden "Sangat Setuju" matrikulasi diadakan untuk topik Jaringan Komputer.

\section{DAFTAR PUSTAKA}

Anwar, Y. 2012. Kemampuan Subject Specific Pedagogy Calon Guru Biologi Peserta Program Pendidikan Profesional Guru (PPG) yang Berlatar Belakang Basic Sains Pra dan PosWorkshop. Jurnal Pendidikan IPA Indonesia, 1(2): 157-162.

Azwar, S. 1998. Sikap Manusia: Teori dan Pengukurannya. Yogyakarta: Liberty.

Departemen Pendidikan Nasional. 2002. Kamus Besar Bahasa Indonesia. Jakarta: Balai Pustaka.

Djamarah, S.B. 2008. Psikologi Belajar. Jakarta: Rineka Cipta.

Gulo. 1996. Strategi Belajar Mengajar. Jakarta: Grasindo.

Gunawan, A. 2016. Pengaruh Kegiatan Matrikulasi Pendidikan Seks dan Kesadaran tentang Bahaya Pornografi terhadap Karakter Peserta Didik. Tsamrah al-Fikri, 10(2016): 155-172.

Hamalik, O. 2010. Proses Belajar Mengajar. Bandung: Bumi Aksara.

Hartati, M. 2017. Respon Mahasiswa mengenai Pelaksanaan Matrikulasi bagi Mahasiswa Baru IKIP PGRI Pontianak. Edukasi: Jurnal Pendidikan, 15(2): 243-252.

Herwandar, R., Safryono, D. A., \& Haryono, P. Y. 2012. Evaluasi Program Matrikulasi "TOEFL" Mahasiswa Universitas Al Azhar Indonesia 2010/2011. Jurnal Al-Azhar Indonesia Seri Humaniora, 1(3): 179-188.

Jeremy, K., Douglas, L. V., Harry, B., \& Deborah, B. 2012. Perceptions of College Students on Social Factors that Influence Student Matriculatioan. College Student Journal, 46(3): 653-664.

Kaptiningrum, P. \& Mubarok, Z. 2016. Efektivitas Program Matrikulasi Bahasa untuk Meningkatkan Kemampuan Speaking Mahasiswa STAIBN Tegal. Shahih, 1(2): 149-165.

Meinarno, E. A. \&Sarwono, S. W. 2010. Psikologi Sosial Edisi 2. Salemba: Penerbit Salemba Humanika.

Misran, N., Aziz, N. A., Arsad, N., Hussain, H., Zaki, W. M. D. W., \& Sahuri, S. N. S. 2012. Influencing Factors for Matriculation Students in Selecting University and Program of Study. UKM Teaching and Learning Congress, 60(2012): 567-574. 
Mitchell, A. B. \& Stewart, J. B. 2012. The Effects of Culturally Responsive Mentoring on the High School to College Matriculation of Urban African American Males. A Journal on Black Men, 1(1): 79-93.

Mudzalir, A. 1997. Psikologi Pendidikan. Jakarta: Pustaka Setia.

Nurnberg, P., Schapiro, M., \& Zimmerman, D. 2012. Students Choosing Colleges: Understanding the Matriculation Decision at a Highly Selective Private Instution. Economics of Education Review, 31(1): 1-8.

Prasad, J. J., Showler, M. B., Ryan, A. M., Schmitt, N., \& Nye, C. D. 2017. When Belief Precedes Being: How Attitudes and Motivation before Matriculation Lead to Fit and Academic Performance. Journal of Vocational Behavior, 100(June 2017): 27-42.

Purwanto, M. N. 1986.Prinsip-Prinsip dan Tehnik Evaluasi Pengajaran. Bandung: Remaja Karya

Rektor Universitas Indonesia. 2008. Keputusan Rektor Universitas Indonesia Nomor 008/SK/R/UI/2008 tentang Penyelenggaraan Perkuliahan Matrikulasi untuk Program Magister dan Doktor di Universitas Indonesia dalam http://repository.ui.ac.id/dokumen/lihat/4192.pdf. Diakses tanggal 29 September 2019.

Rosliana, N., Permanasari, A., \& Sudargo, F. 2014. Gambaran Hasil Belajar Matrikulasi Kimia Kesehatan di Program Studi S1 Kesehatan Masyarakat STIKes Dharma Husada Bandung. Jurnal Pendidikan Matematika dan Sains, 2(2): 187-194.

Sobur, A. 2003. Psikologi Umum. Jakarta: Pustaka Setia.

Soekanto, S. 2007. Sosiologi suatu Pengantar. Jakarta: P.T.Raja. Grafindo.

Sunaiyah, S. 2018. Program Matrikulasi pada Pembelajaran Kurikulum 2013. Indonesian Journal of Islamic Education Studies, 1(1): 115-133.

Syah, M. 2008. Psikologi Belajar. Jakarta: Raja Grafindo Persada.

Syahadati, E., Rodhi, \& Sari, D. S. 2018. Persepsi Mahasiswa terhadap Matrikulasi Mahasiswa Baru. Jurnal Pendidikan Bahasa, 7(1): 16-24. 